\title{
Implementasi Sistem Informasi Dalam Perbaikan Kualitas Laporan Keuangan Pada CV. Tri Agri
}

\author{
Ari Suhartanto ${ }^{1}$, Ridho Pamungkas ${ }^{2}$ \\ ${ }^{1}$ Prodi Informatika, Fakultas Teknik, Universitas Doktor Nugroho Magetan \\ ${ }^{2}$ Universitas PGRI Madiun

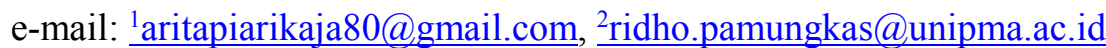

\begin{abstract}
Abstrak - Model pencatatan dan pelaporan keuangan pada CV. Tri Agri memerlukan perubahan karena dalam perjalanan dan perkembangannya masih ditemukan kesalahan serta kecacatan dalam pencatatan pelaporan keuangan. Hal tersebut disebabkan karena kemampuan pada pekerjaan administrasi keuangan yang kurang memadai dari faktor perangkat dan sumber daya manusia (SDM) masih terbatas. Dalam penelitian ini diangkat permasalahan tersebut dengan membangun dan membandingkan kinerja antara model pencatatan manual dengan setelah menggunakan sistem informasi laporan keuangan yang diujicobakan. Pengembangan perangkat lunak dalam penelitian ini menggunakan metode Built and Fix. Hasil dari penelitian ini ditemukan masih memerlukan pendampingan serta penguatan penguasaan operator dalam menjalankan sistem yangtelah dibuat. Hasil uji coba yang dijalankan didapatkan tingkat resiko dapat ditekan karena sistem yang dibangun dapat dijalankan sesuai aturan pencatatan laporan keuangan serta terintegrasi dalam basis data..
\end{abstract}

Kata kunci-Web Laporan Keuangan, CV. Tri Agri, Built and Fix

\section{PENDAHULUAN}

CV. Tri Agri merupakan unit usaha yang bergerak dalam bidang produksi dan penjualan bibit tanaman hias dan buah, serta jasa desain taman dan kolam. Sebagai perusahaan dagang yang professional, $\mathrm{CV}$. Tri Agri memiliki sistem pengelolaan data keuangan yang mencatat seluruh transaksi baik pembelian atau belanja, penggajian pegawai, transaksi penjualan barang dan jasa, serta menghitungnya sebagai laporan laba-rugi perusahaan. Model pencatatan data keuangan pada CV. Tri Agri, masih menggunakan pencatatan secara manual dan belum terkomputerisasi. Model pencatatan keuangan seperti tersebut, sangat beresiko terhadap peluang kesalahan pencatatan atau kehilangan data yang sudah tersimpan. Dengan latar belakang tersebut, maka dalam penelitian ini penulis mengangkat permasalahan Implementasi Sistem Informasi dalam Perbaikan Kualitas Laporan Keuangan Pada CV. Tri Agri. Dengan dibuatnya sistem tersebut, diharapkan dapat membantu perusahaan dalam mengelola data keuangan perusahaan sehingga terhindar dari kesalahan mencatatan atau kehilangan data keuangan perusahaan karena data dikelola dengan menerapkan teknologi informasi yang terintegrasi dengan basis data.

\section{LANDASAN TEORI}

Pemanfaatan Teknologi Informasi merupakan salah satu cara dalam menyelesaikan masalah-masalah yang dihadapi dalam pelaporan keuangan yang terjadi dalam operasional Usaha Kecil dan Menengah (UKM). Sistem Informasi Keuangan adalah sistem informasi yang dirancang untuk menyediakan informasi mengenai arus uang bagi para pemakai di seluruh perusahaan, dalam hal ini termasuk UKM. Untuk memudahkan UKM dengan beberapa area pemasaran dalam hal pelaporan keuangan, dibutuhkan suatu sistem informasi keuangan yang mendukung kelangsungan operasional UKM (Heribertus dkk, 2014).

Sistem informasi akuntansi didefinisikan sebagai susunan berbagai dokumen, alat komunikasi, tenaga pelaksana, dan berbagai laporan yang didesain untuk menginformasikan data keuangan menjadi informasi keuangan (Nugroho Widjajanto, 2001).

Sedangkan menurut Barry E. Cushing dalam Jogianto (2000), Sistem Informasi Akuntansi didefinisikan sebagai kumpulan dari manusia dari sumber-sumber daya modal di dalam organisasi yang bertanggung jawab untuk menyediakan informasi keuangan dan juga informasi yang didapat dari pengumpulan dan pengelolan data transaksi.

Sistem Informasi Keuangan Berbasis web adalah sebuah layanan informasi berbasis web yang dapat dijadikan sebagai referensi (acuan) bagi pengguna dalam menentukan laporan keuangan yang diinginkan sesuai dengan laba - rugi perusahaan.

Pengguna akuntansi juga bervariasi, dari yang sekedar memahami akuntansi sebagai: 1) alat hitung menghitung; 2) sumber informasi dalam pengambilan keputusan; 3) sampai ke pemikiran bagaimana akuntansi diterapkan sejalan dengan (atau sebagai bentuk pengamalan) ajaran agama. Bila dihubungkan dengan kelompok usaha kecil dan menengah tampaknya pemahaman terhadap akuntansi masih berada pada tataran pertama dan kedua yaitu sebagai alat hitungmenghitung dan sebagai sumber informasi untuk pengambilan keputusan (Defiana, 2011).

Laporan keuangan merupakan hasil tindakan pembuatan ringkasan data keuangan perusahaan (Wendri dkk, 2016).

a. Jurnal 
Jurnal merupakan catatan akuntansi permanen yang pertama, yang digunakan untuk mencatat transaksi keuangan perusahaan ( Wendri dkk, 2016).

b. Buku Besar

Buku besar merupakan kumpulan rekening-rekening yang digunakan untuk menyortasi dan meringkas informasi yang telah dicatat dalam jurnal (Wendri dkk, 2016).Laporan Laba Rugi

Laporan laba rugi melaporkan pendapatan dan beban selama periode waktu tertentu (Wendri dkk, 2016).

c. Laporan Ekuitas Pemilik

Laporan ekuitas pemilik merupakan suatu ikhtisar perubahan ekuitas pemilik yang terjadi selama periode waktu tertentu, misalnya sebulan atau setahun (Wendri dkk, 2016).

d. Neraca

Laporan ekuitas pemilik merupakan suatu ikhtisar perubahan ekuitas pemilik yang terjadi selama periode waktu tertentu, misalnya sebulan atau setahun (Wendri dkk, 2016).

Berdasarkan definisi dan gambaran di atas penulis dapat menyimpulkan bahwa proses akuntansi adalah proses kejadian yang terjadi secara sistematis mengenai proses-proses yang dilakukan dalam pengolahan data yang berhubungan dengan kejadian dan transaksi ekonomi yang berhubungan dengan keuangan.

\section{METODE}

Metode yang digunakan dalam penelitian ini adalah metode model build and fix. Metode ini akan melakukan pembuatan dan perbaikan (maintenance) dengan cepat jadi tidak memerlukan waktu berbulanbulan.

Metodologi yang digunakan dalam melakukan perancangan sistem ini yaitu dengan menggunakan model built and fix. Metode pengembangan sistem model built and fix merupakan urutan kegiatanatau aktivitas yang dilakukan dalam pengembangan sistem yang terdiri dari proses Built first version, Modify until customer satisfied,Maintenance, dan Retirement.

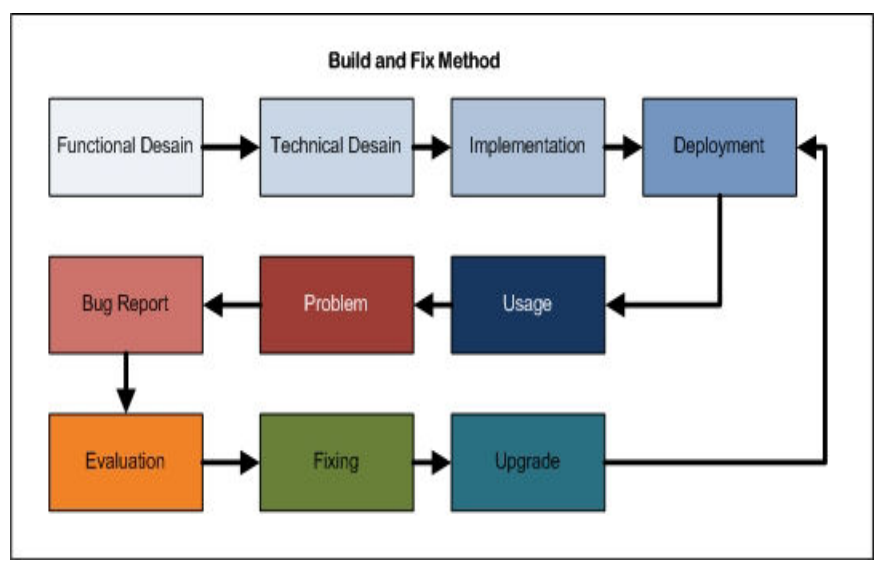

Gambar 1. Metode Pengembangan Built and Fix

\section{HASIL}

\section{a. Tahap Analisis dan Perancangan (Functional Design)}

Model pendataan keuangan pada yang dijalankan masih menggunakan model pencatatan manual untuk pembukuan keuangan data stok barang, penjualan dan juga bertindak sebagai admin keuangan perusahaan. Model pencatatan data dan laporan keuangan CV. Tri Agri seperti dapat dilihat dalam diagram flowchart pada Gambar 2. sebagai berikut;

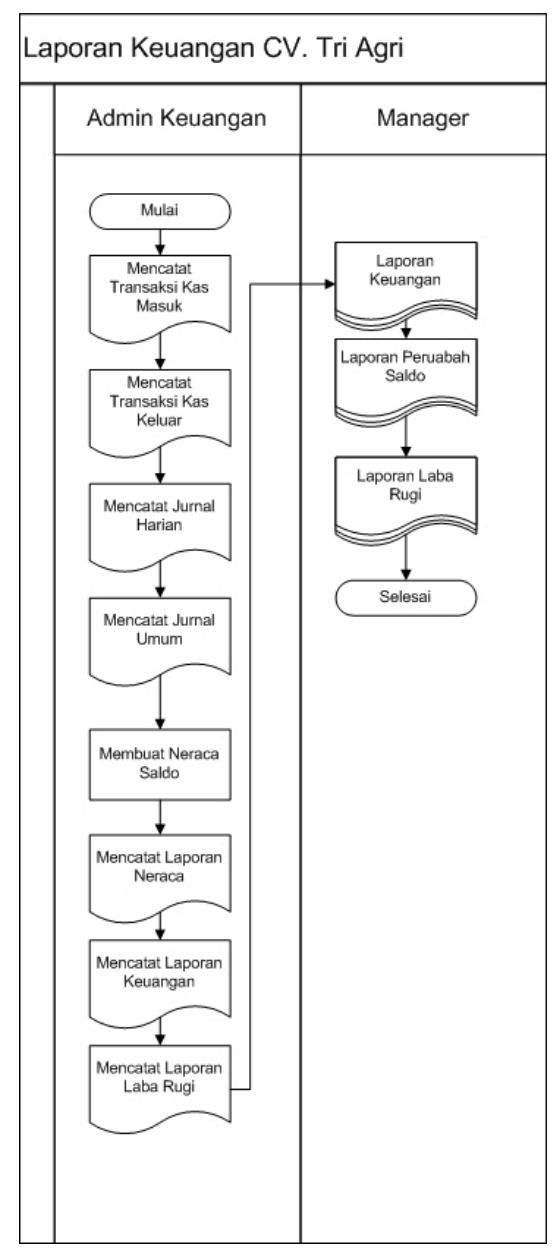

Gambar 2. Flowchart Model Pencacatan Laporan Keuangan

b. Tahap Technical Design dan Implementasi

1. Analisis Kebutuhan Sistem

Spesifikasi sistem informasi keuangan yang dibutuhkan yaitu:

a) Web based system, dimana dapat dioperasikan di berbagai sistem operasi, dapat menjadikan software versi open source yang tidak memerlukan lisensi untuk mendapatkan dan mengoperasikan sehingga menghemat biaya operasional.

b) Sistem yang dibuat ini hanya dijalankan oleh admin untuk mengelola data keuangan dan mencetak 
laporan untuk diserahkan kepada pimpinan (pemilik).

c) Laporan yang dihasilkan dari sistem ini adalah laporan jurnal kas masuk, laporan kas keluar, laporan jurnal harian, rekap jurnal harian, laporan buku besar, laporan laba/rugi dan laporan neraca.

2. Perancangan Sistem

a) Diagram Use Case

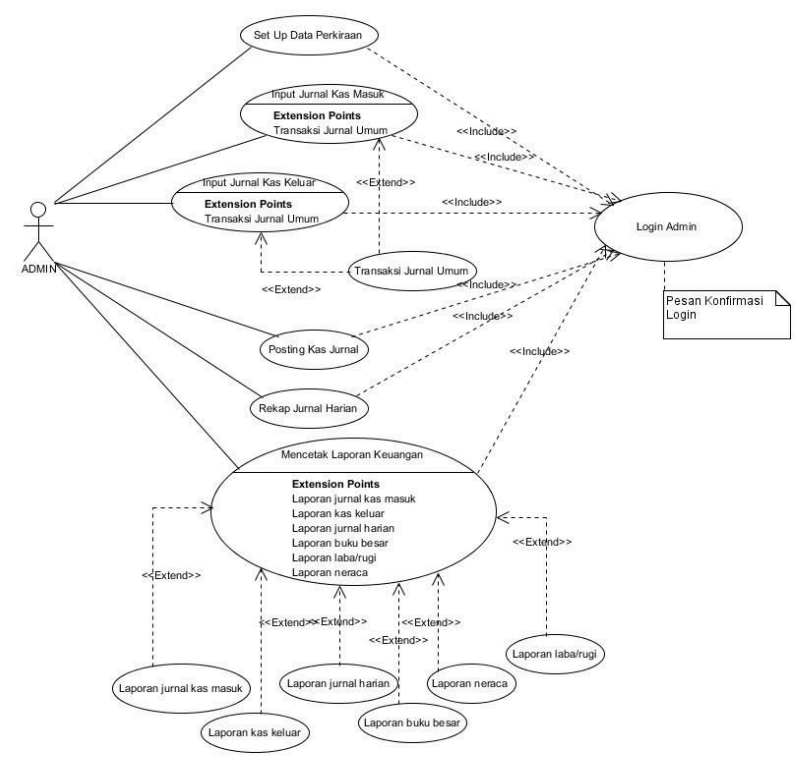

Gambar 3: Diagram Use Case

b) Class Diagram

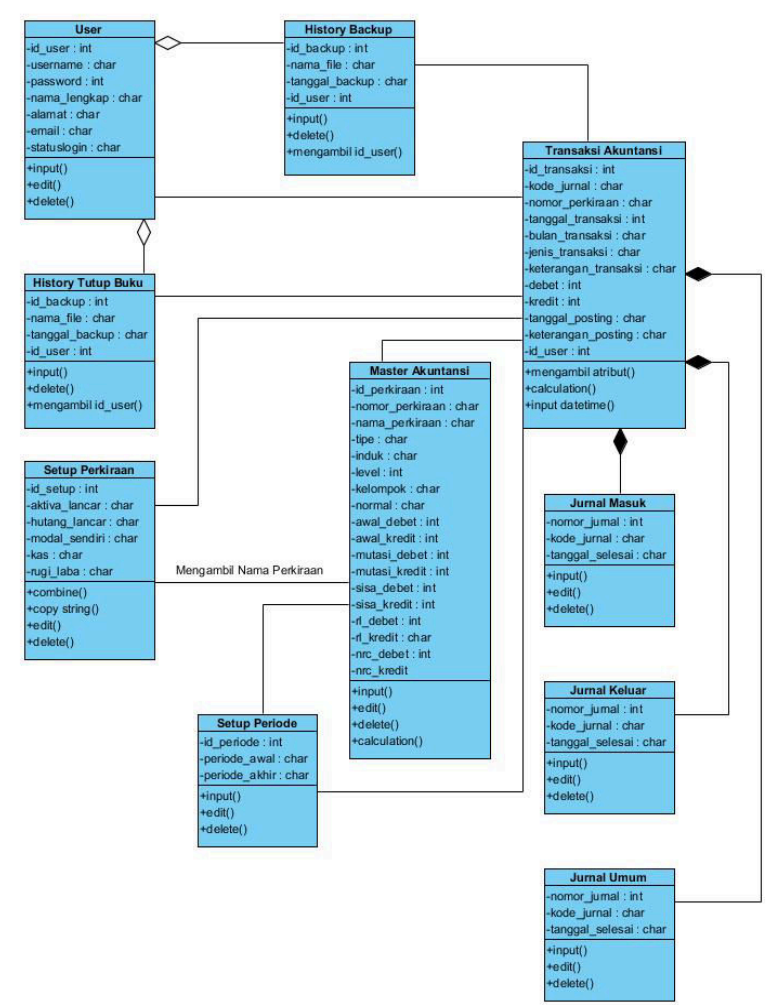

Gambar 4: Class Diagram

c) Activity Diagram

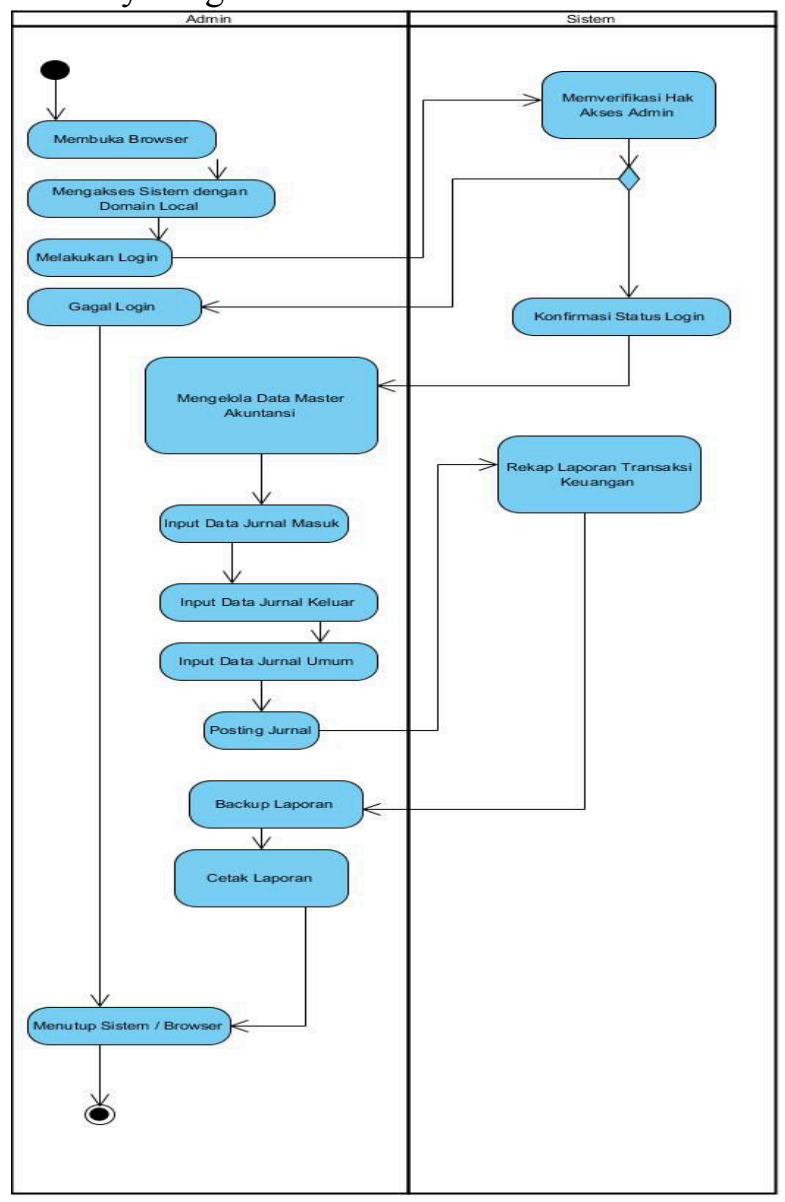


Gambar 5: Activity Diagram

c. Tahap Deployment dan Evaluasi Sistem

1. Implementasi Sistem

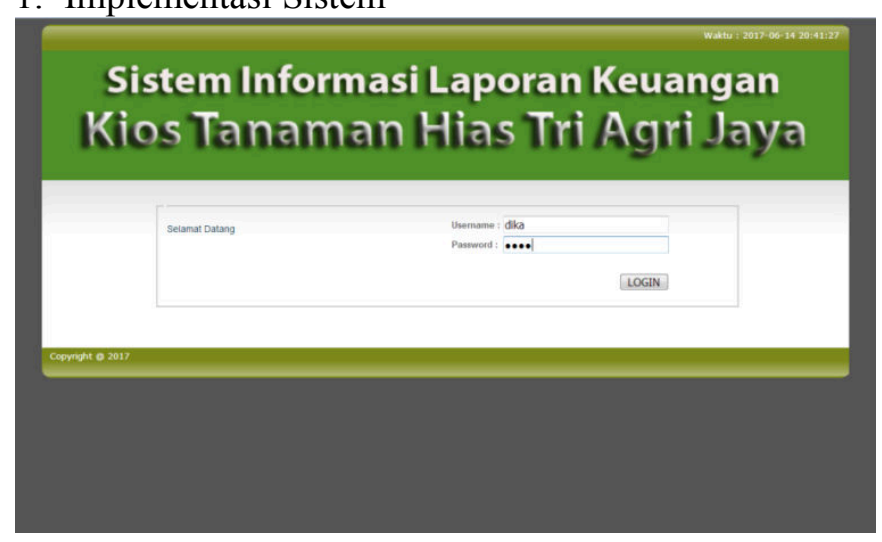

Gambar 6: Tampilan Sistem

\section{Evaluasi Hasil Penerapan Sistem}

Tahap akhir dari penelitian ini yaitu melakukan pengujian sebagai evaluasi dari sistem yang dibuat dengan metode Black Box. Dari seluruh proses kerja dalam sistem ini dijalankan dengan dua uji coba yaitu menjalankan dengan prosedur yang sesuai dengan aturan serta menjalankan proses kerja dengan kemungkinan kesalahan yang dibuat. Dari hasil proses yang dijalankan dalam sistem, maka penulis membandingkan hasil output dari sistem dengan hasil yang diharapkan sesuai tahap perancangan dan desain sistem sesuai dengan analisis kebutuhan sistem pelaporan keuangan perusahaan CV. Tri Agri. Tahap pengujian ini divalidasi oleh pimpinan perusahaan serta tim akunting yang ditunjuk oleh pemilik perusahaan, sebagai pihak ahli dalam pelaporan keuangan perusahaan dagang. Berdasarkan hasil dari pengujian tersebut, dinyatakan bahwa seluruh proses kerja sistem sudah berjalan sesuai dengan desain dan perancangan serta dapat berjalan sesuai prosedur pencatatan pelaporan keuangan.

\section{Kesimpulan}

Berdasarkan hasil analisis yang telah diuraikan pada pembahasan masalah dan bab sebelumnya, penulis dapat menarik kesimpulan bahwa sistem informasi akuntansi penjualan merupakan "organisasi pengelolaan informasi yang terdiri dari penyediaan formulir, catatan, dan laporan mengenai penjualan yang dikoordinasikan sedemikian rupa untuk menyediakan informasi keuangan yang dibutuhkan oleh manajemen guna memudahkan pengelolaan perusahaan.

Salah satu permasalahan yang masih dihadapi oleh CV. Tri Agri, masih ada kesenjangan dan keterbatasan kemampuan dan pengetahuan pegawai dalam menjalankan sistem informasi keuangan yang dibuat, sehingga sering terjadinya kesalahan pemasukan data transaksi serta peluang keterlambatan tanggal input data apabila terjadi kerusakan ringan pada unit komputer dan administrasi jaringan. Guna mengatasi hal ini, disarankan pemilik perusahaan untuk selalu mendampingi dan meningkatkan pengetahuan serta kemampuan pegawai adminstrasi melalui pendidikan dan pelatihan dalam bidang sistem informasi dan pengoperasian sistem serta jaminan kualitas perangkat komputer dan jaringan.

\section{DAFTAR PUSTAKA}

[1] Abdurrachman, A. 1991. Ensiklopedia Ekonomi, Keuangan, Perdagangan Edisi 2 Cetakan 6. Jakarta: PT Pradnya Paramita.

[2] Anhar.2010. Panduan Menguasai PHP dan Mysql secara Otodidak, Jakarta: Media kita

[3] Anisyah, 2000, Analisa dan Desain Sistem Informasi, Yogyakarta, Penerbit Andi.

[4] Arief S. Sadiman, dkk. 2009. Media Pendidikan, Pengertian, Pengembangan, dan Pemanfaatannya. Jakarta: Rajawali Press.

[5] Atmaja, Lukas Setia. 2008. Teori \& Praktik Manajemen Keuangan. Yogyakarta: Andi.

[6] Bin Ladjamudin, Al-Bahra. 2005. Analisis dan Desain Sistem Informasi. Yogyakarta: Graha Ilmu.

[7] Booch, G. James, R. Ivar, J, 2005. The Unified Modeling Language User Guide Second Edition. United State: Addison Wesley Professional.

[8] Buyens, Jim. 2001. Web Database Development. Elex Media Komputindo. Jakarta

[9] Daulay , Melwin Syafrizal. 2007. Mengenal Hardware-Software dan Pengelolaan Instalasi Komputer. Yogyakarta: Andi.

[10] Effrin, Sujoko. 2004. Metode Penelitian Akuntansi Yogyakarta: Graha Ilmu.

[11] Halim, Abdul. 2004. Akuntansi Sektor Publik Akuntansi Keuangan Daerah. Jakarta: Salemba Empat.

[12] Heribertus dkk, 2014 . Rancang Bangun Sistem Informasi Keuangan Berbasis Area untuk Pengusaha Kecil (Studi Kasus Batik Wijayanti Semarang) . Jurnal Teknologi Informasi DINAMIK Volume 19, No.2, Juni 2014 : 137-143 ISSN : 08549524

[13] Ikatan Akuntan Indonesia. 2009. Standar Akuntansi Keuangan. Jakarta: Salemba Empat.

[14] Ikhsan, Arfan 2010. Akuntansi dan Manjemen Keuangan Rumah Sakit Jakarta: Graha Ilmu

[15] Jogiyanto HM. 2005. Analisis dan Desain Sistem Informasi. Yogyakarta : Andi Offset.

[16] Kadir, Abdul. 2009. Membuat Aplikasi Web dengan PHP + Database MySQL. Yogyakarta: Andi

[17] Media Komputer. 2010. Panduan Belajar MySQL Database Server. Wahana Komputer.

[18] Mulyadi. 2001. Sistem Akuntansi Edisi Ke-3. Jakarta: Salemba Empat.

[19] Peranginangin, Kasiman 2006. Aplikasi Web dengan PHP dan MySQL Yogyakarta: Andi

[20] Rizky Dhanta. 2009. Pengantar Ilmu Komputer. Surabaya: INDAH.

[21] Sari, Defiana Innama, 2011 . Pembuatan Sistem Informasi Keuangan Berbasis Web Pada Ud.Saputra Jaya . Naskah Publikasi Jurusan Sistem Informasi Sekolah Tinggi Manajemen Informatika Dan Komputer Amikom Yogyakarta 2011

[22] Simonn Bennet, Steve Marcob, Ray Farmer. 2006. ObjectOriented Systems Analysis and Design Using UML. New York: McGraw Hill.

[23] Soemarso. 2004. Akuntansi Suatu Pengantar Buku 1 Edisi 5. Jakarta: Salemba Empat. 
[24] Sridadi, Bambang .2009, Pemodelan dan system simulasi system teori, aplikasi dan contoh program dalam bahasa c, Informatika, Bandung

[25] Sugiyono. 2007. Metodologi Penelitian Bisnis cetakan ke-15. Bandung: Alfabeta.

[26] Susanto, Azhar. 2009. Sistem Informasi Manajemen. Bandung: Linggajaya.

[27] Susanto, Azhar. 2009. Sistem Informasi Manajemen. Bandung: Linggajaya.

[28] Sutabri, Tata. 2004 . Analisa Sistem Informasi. Yogyakarta: Andi

[29] Wendri dkk, 2016 . Sistem Informasi Keuangan pada Sekolah ST.Agatha . Jurusan Sistem Informasi STMIK GI MDP 